\title{
Kinetics and Mechanism of the Anilinolysis of Diisopropyl Thiophosphinic Chloride in Acetonitrile
}

\author{
Md. Ehtesham Ul Hoque and Hai Whang Lee* \\ Department of Chemistry, Inha University, Incheon 402-751, Korea. *E-mail: hwlee@inha.ac.kr \\ Received August 18, 2011, Accepted August 31, 2011
}

\begin{abstract}
The nucleophilic substitution reactions of diisopropyl thiophophinic chloride (3) with substituted anilines $\left(\mathrm{XC}_{6} \mathrm{H}_{4} \mathrm{NH}_{2}\right)$ and deuterated anilines $\left(\mathrm{XC}_{6} \mathrm{H}_{4} \mathrm{ND}_{2}\right)$ are investigated kinetically in acetonitrile at $65.0{ }^{\circ} \mathrm{C}$. The anilinolysis rate of $\mathbf{3}$ is rather slow to be rationalized by the conventional stereoelectronic effects. The obtained deuterium kinetic isotope effects (DKIEs; $\left.k_{\mathrm{H}} / k_{\mathrm{D}}\right)$ are secondary inverse $\left(k_{\mathrm{H}} / k_{\mathrm{D}}=0.80-0.96\right)$. The anilinolyses of ten $\mathrm{P}=\mathrm{S}$ systems in $\mathrm{MeCN}$ are reviewed on the basis of DKIEs and selectivity parameters to obtain systematic information on the DKIEs and mechanism for thiophosphoryl transfer reactions. The steric effects of the two ligands on reactivity, DKIEs, mechanism, and substituent effects of the nucleophile (X) on the DKIEs are discussed.
\end{abstract}

Key Words : Phosphoryl transfer reaction, Anilinolysis, Diisopropyl thiophosphinic chloride, Deuterium kinetic isotope effect

\section{Introduction}

A considerable amount of work has been focused on the two types of phosphoryl and thiophosphoryl transfer reaction mechanisms; stepwise through a trigonal bipyramidal pentacoordinate (TBP-5C) intermediate, and concerted through a single pentacoordinate transition state (TS). The attacking direction of the nucleophile can be backside and/or frontside, depending on the substrate, nucleophile, leaving group, and reaction condition. In previous work, this lab reported upon various types of phosphoryl and thiophosphoryl transfer reactions: anilinolysis, ${ }^{1}$ pyridinolysis, ${ }^{2}$ benzylaminolysis, ${ }^{3}$ and theoretical study. ${ }^{4}$ The kinetics and mechanism of the anilinolysis of various substrates in acetonitrile $(\mathrm{MeCN})$ were investigated by means of the deuterium kinetic isotope effects (DKIEs; $k_{\mathrm{H}} / k_{\mathrm{D}}$ ) involving deuterated anilines $\left(\mathrm{XC}_{6} \mathrm{H}_{4} \mathrm{ND}_{2}\right)$, selectivity parameters $\left(\rho_{\mathrm{X}}\right.$, $\left.\beta_{\mathrm{X}}, \rho_{\mathrm{Y}}, \rho_{\mathrm{XY}}\right)$, and steric effects of the two ligands.

The DKIEs can be only secondary inverse $\left(k_{\mathrm{H}} / k_{\mathrm{D}}<1\right)$ in a normal $\mathrm{S}_{\mathrm{N}} 2$ reaction, since the N-H(D) vibrational frequencies invariably increase upon going to the TS (in-line-type $\mathrm{TSb}$ in Scheme 1; backside nucleophilic attack), given the increase in steric hindrance in the bond formation step; the greater the bond formation, the greater the steric congestion occurs, and the smaller the $k_{\mathrm{H}} / k_{\mathrm{D}}$ value becomes. ${ }^{5}$ In

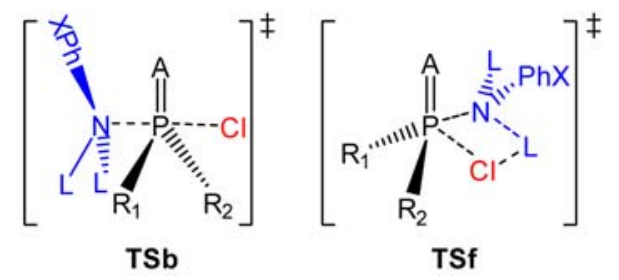

Scheme 1. Backside attack TSb and frontside attack TSf $(A=O$ or $\mathrm{S} ; \mathrm{L}=\mathrm{H}$ or $\mathrm{D})$. contrast, when partial deprotonation of the aniline occurs in a rate-limiting step by hydrogen bonding (hydrogen-bonded, four-center-type TSf in Scheme 1; frontside nucleophilic attack), the DKIEs are primary normal $\left(k_{\mathrm{H}} / k_{\mathrm{D}}>1\right)$; the greater the extent of the hydrogen bond that occurs, the greater the $k_{\mathrm{H}} / k_{\mathrm{D}}$ value becomes. ${ }^{6}$ When the reaction proceeds simultaneously through both pathways, backside (TSb) and frontside (TSf) attack, the observed DKIEs are the sum of both effects, primary normal and secondary inverse, and the obtained value of $k_{\mathrm{H}} / k_{\mathrm{D}}$ can be greater or lesser than the unity depending on the proportion of the two pathways. Thus, the DKIEs can be one of the strong tools to substantiate the TS structure.

The cross-interaction constant (CIC) is also one of the strong tools to clarify the reaction mechanism. The CIC, $\rho_{\mathrm{XY}}$, is negative in a normal $\mathrm{S}_{\mathrm{N}} 2$ reaction (or in a stepwise reaction with a rate-limiting bond formation), and positive in a stepwise reaction with a rate-limiting leaving group expulsion from the intermediate. The magnitude of the CIC is inversely proportional to the distance between $\mathrm{X}$ and $\mathrm{Y}$ through the reaction center; the tighter the TS, the greater the magnitude of the CIC. Here, X and Y denote the substituents of the nucleophile and substrate, respectively. ${ }^{7}$

$$
\begin{gathered}
\log \left(k_{\mathrm{XY}} / k_{\mathrm{HH}}\right)=\rho_{\mathrm{X}} \sigma_{\mathrm{X}}+\rho_{\mathrm{Y}} \sigma_{\mathrm{Y}}+\rho_{\mathrm{XY}} \sigma_{\mathrm{X}} \sigma_{\mathrm{Y}} \\
\rho_{\mathrm{XY}}=\partial \rho_{\mathrm{X}} / \partial \sigma_{\mathrm{Y}}=\partial \rho_{\mathrm{Y}} / \partial \sigma_{\mathrm{X}}
\end{gathered}
$$

In the present work, the DKIEs and reaction mechanism for the reactions of diisopropyl thiophosphinic chloride [3: $i$ - $\mathrm{Pr}_{2} \mathrm{P}(=\mathrm{S}) \mathrm{Cl}$ ] with $\mathrm{XC}_{6} \mathrm{H}_{4} \mathrm{NH}_{2}\left(\mathrm{D}_{2}\right)$ in $\mathrm{MeCN}$ at $65.0^{\circ} \mathrm{C}$ (Scheme 2) are examined first to gain further information on the thiophosphoryl transfer reaction mechanism. The B3LYP/ $6-311+\mathrm{G}(\mathrm{d}, \mathrm{p})^{8}$ geometry, dihedral bond angles, and natural bond order (NBO) charges of $\mathbf{3}$ in the gas phase are shown in Figure 1. The MO theoretical structure shows that the two 


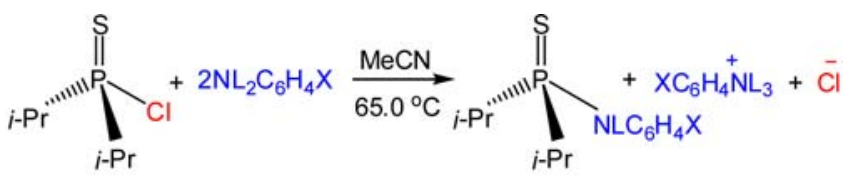

$\mathrm{L}=\mathrm{H}$ or $\mathrm{D}$

$\mathrm{X}=4-\mathrm{MeO}, 4-\mathrm{Me}, 3-\mathrm{Me}, \mathrm{H}, 3-\mathrm{MeO}, 4-\mathrm{Cl}, 3-\mathrm{Cl}$

Scheme 2. The studied reaction system.

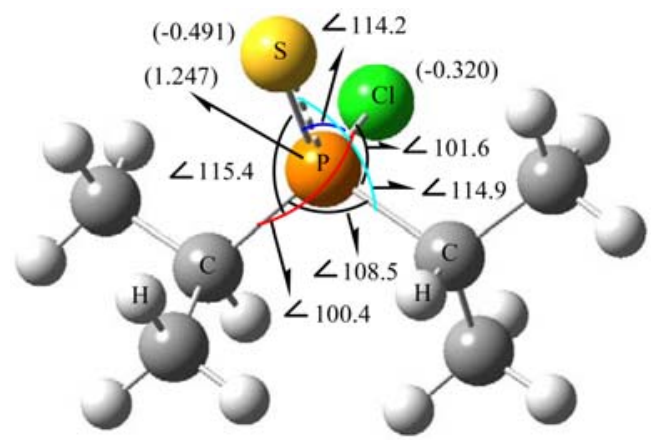

Figure 1. The B3LYP/6-311+G(d,p) geometry of diisopropyl thiophosphinic chloride (3) in the gas phase.

carbons, sulfur, and chlorine have more or less distorted tetrahedral geometry with the phosphorus atom at the center.

Secondly the anilinolyses of ten $\mathrm{P}=\mathrm{S}$ systems in $\mathrm{MeCN}$ are reviewed on the basis of DKIEs and selectivity parameters to obtain systematic information on the DKIEs and mechanism for thiophosphoryl transfer reactions. The ten substrates with $\mathrm{Cl}$ leaving group are divided into three groups, thiophosphinic chlorides, phosphonochloridothioates, and chlorothiophosphates: (i) group I (1-4: $\mathrm{R}_{1} \mathrm{R}_{2} \mathrm{P}(=\mathrm{S}) \mathrm{Cl}$ type): dimethyl [1: $\left.\mathrm{Me}_{2} \mathrm{P}(=\mathrm{S}) \mathrm{Cl}\right],{ }^{1 \mathrm{j}}$ diethyl $\left[2: \mathrm{Et}_{2} \mathrm{P}(=\mathrm{S}) \mathrm{Cl}\right],{ }^{1 \mathrm{p}}$ diisopropyl [3: $\left.i-\mathrm{Pr}_{2} \mathrm{P}(=\mathrm{S}) \mathrm{Cl}\right]$, and diphenyl $\left[4: \mathrm{Ph}_{2} \mathrm{P}(=\mathrm{S}) \mathrm{Cl}\right]^{1 \mathrm{e}}$ thiophosphinic chlorides; (ii) group II [5-6: $\mathrm{R}_{1}\left(\mathrm{R}_{2} \mathrm{O}\right) \mathrm{P}(=\mathrm{S}) \mathrm{Cl}-$ type]: $O$-aryl methyl [5: $\left.\mathrm{Me}\left(\mathrm{YC}_{6} \mathrm{H}_{4} \mathrm{O}\right) \mathrm{P}(=\mathrm{S}) \mathrm{Cl}\right]^{1 \mathrm{k}}$ and $O$-aryl phenyl [6: $\left.\mathrm{Ph}\left(\mathrm{YC}_{6} \mathrm{H}_{4} \mathrm{O}\right) \mathrm{P}(=\mathrm{S}) \mathrm{Cl}\right]^{1 \mathrm{q}}$ phosphonochloridothioates; and (iii) group III [7-10: $\left(\mathrm{R}_{1} \mathrm{O}\right)\left(\mathrm{R}_{2} \mathrm{O}\right) \mathrm{P}(=\mathrm{S}) \mathrm{Cl}$-type]: dimethyl [7: $\left.(\mathrm{MeO})_{2} \mathrm{P}(=\mathrm{S}) \mathrm{Cl}\right],{ }^{\mathrm{lg}}$ diethyl $\left[8:(\mathrm{EtO})_{2} \mathrm{P}(=\mathrm{S}) \mathrm{Cl}\right],{ }^{1 \mathrm{~g}}$ Y-aryl ethyl [9: $\left.(\mathrm{EtO})\left(\mathrm{YC}_{6} \mathrm{H}_{4} \mathrm{O}\right) \mathrm{P}(=\mathrm{S}) \mathrm{Cl}\right],{ }^{1 \mathrm{f}}$ and Y-aryl phenyl [10: $\left.(\mathrm{PhO})\left(\mathrm{YC}_{6} \mathrm{H}_{4} \mathrm{O}\right) \mathrm{P}(=\mathrm{S}) \mathrm{Cl}\right]^{\text {lc }}$ chlorothiophosphates, where $R_{1}$ and $R_{2}$ are alkyl and/or phenyl group. The numbering of the substrates of each group follows the sequence of the size of the two ligands. The following points are then discussed: (i) the steric effects of the two ligands on reactivity of the substrate; (ii) the DKIEs on the $\mathrm{P}=\mathrm{S}$ systems; (iii) the anilinolysis mechanism; (iv) the substituent effects of the nucleophile (X) on the DKIEs. Henceforth, for convenience in expressing the substrates, $\mathrm{R}_{1} \mathrm{R}_{2} \mathrm{P}(=\mathrm{S}) \mathrm{Cl}$, $\mathrm{R}_{1}\left(\mathrm{R}_{2} \mathrm{O}\right) \mathrm{P}(=\mathrm{S}) \mathrm{Cl}$, and $\left(\mathrm{R}_{1} \mathrm{O}\right)\left(\mathrm{R}_{2} \mathrm{O}\right) \mathrm{P}(=\mathrm{S}) \mathrm{Cl}$ are denoted as $\mathrm{S}\left(\mathrm{R}_{1}, \mathrm{R}_{2}\right), \mathrm{S}\left(\mathrm{R}_{1}, \mathrm{R}_{2} \mathrm{O}\right)$, and $\mathrm{S}\left(\mathrm{R}_{1} \mathrm{O}, \mathrm{R}_{2} \mathrm{O}\right)$, respectively.

\section{Results and Discussion}

The observed pseudo-first-order rate constants $\left(k_{\mathrm{obsd}}\right)$ were found to follow eq. (2) for all of the reactions under pseudo-
Table 1. The Second-Order Rate Constants $\left(k_{\mathrm{H}(\mathrm{D})} \times 10^{5} / \mathrm{M}^{-1} \mathrm{~s}^{-1}\right)$, Selectivity Parameters $\left(\rho_{\mathrm{X}}\right.$ and $\left.\beta_{\mathrm{X}}\right){ }^{a}$ and DKIEs $\left(k_{\mathrm{H}} / k_{\mathrm{D}}\right)$ of the Reactions of Diisopropyl Thiophosphinic Chloride (3) with $\mathrm{XC}_{6} \mathrm{H}_{4} \mathrm{NH}_{2}\left(\mathrm{D}_{2}\right)$ in $\mathrm{MeCN}$ at $65.0^{\circ} \mathrm{C}$

\begin{tabular}{cccc}
\hline $\mathrm{X}$ & $k_{\mathrm{H}} \times 10^{5}$ & $k_{\mathrm{D}} \times 10^{5}$ & $k_{\mathrm{H}} / k_{\mathrm{D}}$ \\
\hline $4-\mathrm{MeO}$ & $52.0 \pm 0.4^{b}$ & $64.9 \pm 0.5$ & $0.801 \pm 0.008^{g}$ \\
$4-\mathrm{Me}$ & $29.4 \pm 0.1$ & $35.1 \pm 0.3$ & $0.838 \pm 0.008$ \\
$3-\mathrm{Me}$ & $12.9 \pm 0.1$ & $15.2 \pm 0.1$ & $0.849 \pm 0.009$ \\
$\mathrm{H}$ & $9.10 \pm 0.06$ & $10.2 \pm 0.1$ & $0.892 \pm 0.011$ \\
$3-\mathrm{MeO}$ & $4.30 \pm 0.03$ & $4.70 \pm 0.04$ & $0.915 \pm 0.010$ \\
$4-\mathrm{Cl}$ & $2.11 \pm 0.02$ & $2.27 \pm 0.02$ & $0.930 \pm 0.012$ \\
$3-\mathrm{Cl}$ & $0.950 \pm 0.009$ & $0.989 \pm 0.007$ & $0.961 \pm 0.011$ \\
$-\rho_{\mathrm{X}}$ & $2.74 \pm 0.03^{c}$ & $2.86 \pm 0.03^{e}$ & \\
$\beta_{\mathrm{X}}$ & $0.97 \pm 0.03^{d}$ & $1.01 \pm 0.04^{f}$ & \\
\hline
\end{tabular}

${ }^{a}$ The $\sigma$ values were taken from ref. 11. The $\mathrm{p} K_{\mathrm{a}}$ values of $\mathrm{X}$-anilines in water were taken from ref. 12. ${ }^{b}$ Standard deviation. ${ }^{c}$ Correlation coefficient, $\mathrm{r}=0.999 .{ }^{d} \mathrm{r}=0.999 .{ }^{e} \mathrm{e}=0.999 .{ }^{{ }} \mathrm{r}=0.999 .{ }^{g}$ Standard error $\{=$ $\left.1 / k_{\mathrm{D}}\left[\left(\Delta k_{\mathrm{H}}\right)^{2}+\left(k_{\mathrm{H}} / k_{\mathrm{D}}\right)^{2} \times\left(\Delta k_{\mathrm{D}}\right)^{2}\right]^{1 / 2}\right\}$ from ref. 13 .

first-order conditions with a large excess of aniline nucleophile. The $k_{0}$ values were negligible $\left(k_{0} \approx 0\right)$ in $\mathrm{MeCN}$. The second-order rate constants $\left(k_{\mathrm{H}(\mathrm{D})}\right)$ were determined for at least five concentrations of anilines. The linear plots of eq. (2) suggest that there are no base-catalysis or noticeable side reactions and that the overall reaction is described by Scheme 2.

$$
k_{\text {obsd }}=k_{0}+k_{\mathrm{H}(\mathrm{D})}\left[\mathrm{XC}_{6} \mathrm{H}_{4} \mathrm{NH}_{2}\left(\mathrm{D}_{2}\right)\right]
$$

The $k_{\mathrm{H}}$ and $k_{\mathrm{D}}$ values are summarized in Table 1 , together with the DKIEs $\left(k_{\mathrm{H}} / k_{\mathrm{D}}\right)$ and the Hammett $\rho_{\mathrm{X}}$ and Brönsted $\beta_{\mathrm{X}}$ selectivity parameters. The $\mathrm{p} K_{\mathrm{a}}(\mathrm{X})$ values of the $\mathrm{X}$ anilines in water were used to obtain the Brönsted $\beta_{\mathrm{X}}$ values in $\mathrm{MeCN}$, and this procedure was justified experimentally and theoretically. ${ }^{9}$ The values of $\mathrm{p} K_{\mathrm{a}}(\mathrm{X})$ and $\sigma_{\mathrm{X}}$ of the deuterated $\mathrm{X}$-anilines are assumed to be identical to those of the $\mathrm{X}$-anilines. The $\mathrm{p} K_{\mathrm{a}}(\mathrm{X})$ values of deuterated $\mathrm{X}$-anilines may be slightly greater than those of $\mathrm{X}$-anilines, however, the difference is too small to be taken into account. ${ }^{10}$ Figures 2 and 3 show the Hammett $\left(\log k_{\mathrm{H}(\mathrm{D})} v s \sigma_{\mathrm{X}}\right)$ and Brönsted $\left[\log k_{\mathrm{H}(\mathrm{D})} v s \mathrm{p} K_{\mathrm{a}}(\mathrm{X})\right]$ plots, respectively, for substituent $\mathrm{X}$ variations in the nucleophiles. The rates are faster with a stronger nucleophile $\left(\rho_{\mathrm{X}}<0\right.$ and $\left.\beta_{\mathrm{X}}>0\right)$ which are compatible with typical nucleophilic substitution reactions with positive charge development at the nucleophile $\mathrm{N}$ atom in the TS. The magnitudes of the $\rho_{\mathrm{X}(\mathrm{D})}(=-2.86)$ and $\beta_{\mathrm{X}(\mathrm{D})}$ $(=1.01)$ values with deuterated anilines are somewhat larger than those $\left(\rho_{\mathrm{X}(\mathrm{H})}=-2.74\right.$ and $\left.\beta_{\mathrm{X}(\mathrm{H})}=0.97\right)$ with anilines. The secondary inverse DKIEs $\left(k_{\mathrm{H}} / k_{\mathrm{D}}<1\right)$ are observed all of the nucleophiles and the values of DKIEs invariably increase as the nucleophile changes from $\mathrm{X}=4-\mathrm{MeO}\left(k_{\mathrm{H}} / k_{\mathrm{D}}=0.801\right)$ to $\mathrm{X}=3-\mathrm{Cl}\left(k_{\mathrm{H}} / k_{\mathrm{D}}=0.961\right)$.

The second-order rate constants $\left(k_{\mathrm{H}}\right)$ with unsubstituted aniline at $55.0^{\circ} \mathrm{C}$, summary of NBO charges at the reaction center $P$ atom $[\mathrm{B} 3 \mathrm{LYP} / 6-311+\mathrm{G}(\mathrm{d}, \mathrm{p})]$ in the gas phase, Brönsted coefficients $\left(\beta_{\mathrm{X}(\mathrm{H})}\right)$, CICs $\left(\rho_{\mathrm{XY}}\right)$, DKIEs $\left(k_{\mathrm{H}} / k_{\mathrm{D}}\right)$, and the variation trends of DKIEs depending on the substituent $\mathrm{X}$ in the nucleophiles of the reactions of 1-10 


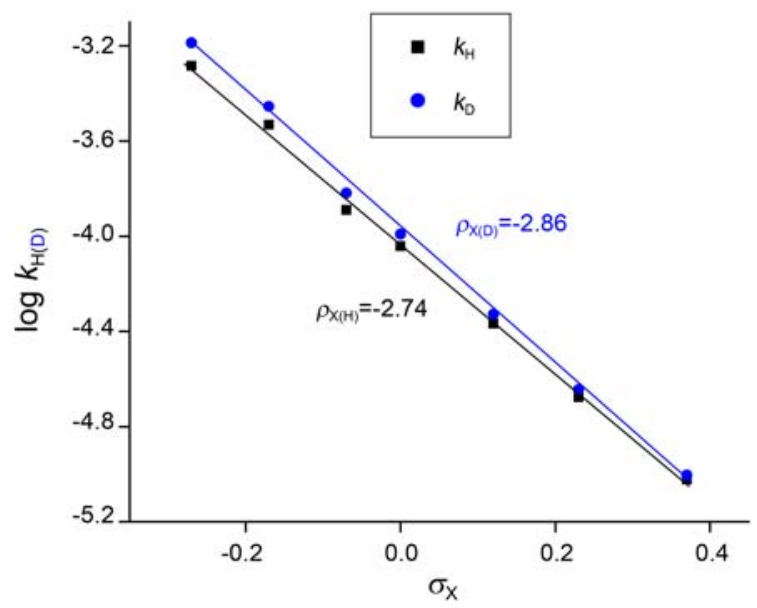

Figure 2. The Hammett plots $\left(\log k_{\mathrm{H}(\mathrm{D})} v s \sigma_{\mathrm{X}}\right)$ of the reactions of diisopropyl thiophosphinic chloride (3) with $\mathrm{XC}_{6} \mathrm{H}_{4} \mathrm{NH}_{2}\left(\mathrm{D}_{2}\right)$ in $\mathrm{MeCN}$ at $65.0^{\circ} \mathrm{C}$.

with $\mathrm{XC}_{6} \mathrm{H}_{4} \mathrm{NH}_{2}\left(\mathrm{D}_{2}\right)$ in $\mathrm{MeCN}$ are summarized in Table 2. The variation trends of DKIEs with $\mathrm{X}$ are represented with arrow. The vertical arrows ( $\uparrow$ or $\downarrow$ ) indicate the direction of the consistent increase of the $k_{\mathrm{H}} / k_{\mathrm{D}}$ values with $\mathrm{X}$. For example, $\uparrow$ indicates that DKIE increases with a stronger nucleophile. The vertical right-left arrow $(\uparrow)$ indicates unsystematic variation trends with $\mathrm{X}$.

Steric Effects of the Two Ligands on Reactivities of the $\mathbf{P}=\mathbf{S}$ Systems. The NBO charges on the $\mathrm{P}$ reaction center are roughly consistent with what would be expected when considering the inductive effects of the ligands. Solely considering the inductive effects of the ligands, the reactivities of the substrates should be proportional to the NBO charge on P. However, the sequence of the second-order rate constants of all three groups is inconsistent with the expectations for the inductive effects of the ligands and the NBO charge on the P reaction center. Thus, it is clear that the inductive effects of the ligands do not play an important role in determining the reactivities of the two systems.

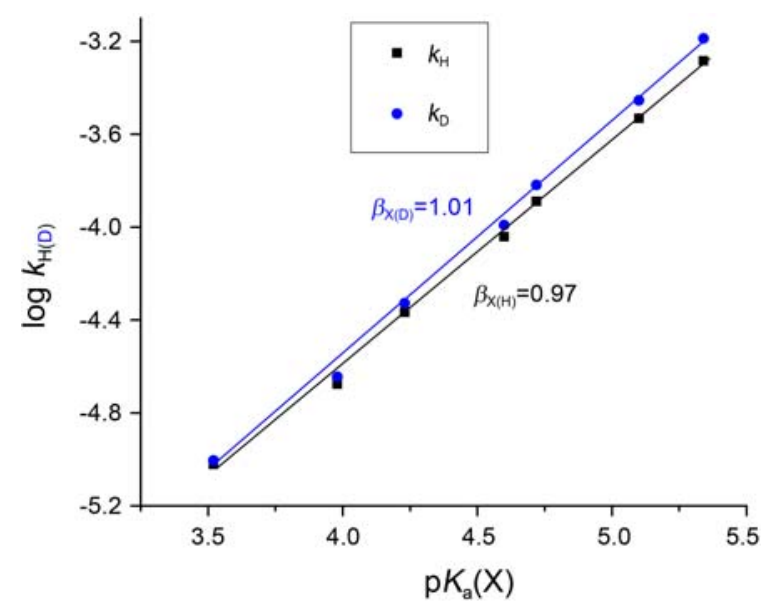

Figure 3. The Brönsted plots $\left[\log k_{\mathrm{H}(\mathrm{D})} v s \mathrm{p} K_{\mathrm{a}}(\mathrm{X})\right]$ of the reactions of diisopropyl thiophosphinic chloride (3) with $\mathrm{XC}_{6} \mathrm{H}_{4} \mathrm{NH}_{2}\left(\mathrm{D}_{2}\right)$ in $\mathrm{MeCN}$ at $65.0{ }^{\circ} \mathrm{C}$.

In groups II and III, it is evident that the relative reactivities are mainly determined by steric effects over inductive effects of the two ligands. The larger the two ligands, the anilinolysis rate becomes slower: group II; $k_{\mathrm{H}} \times 10^{3}$ $\left[\mathrm{S}\left(\mathrm{R}_{1}, \mathrm{R}_{2} \mathrm{O}\right)\right]=7.25[\mathrm{~S}(\mathrm{Me}, \mathrm{PhO})]>1.50[\mathrm{~S}(\mathrm{Ph}, \mathrm{PhO})]$ and group III; $k_{\mathrm{H}} \times 10^{3}\left[\mathrm{~S}\left(\mathrm{R}_{1} \mathrm{O}, \mathrm{R}_{2} \mathrm{O}\right)\right]=1.09[\mathrm{~S}(\mathrm{MeO}, \mathrm{MeO})]>$ $0.512[\mathrm{~S}(\mathrm{EtO}, \mathrm{EtO})]>0.280[\mathrm{~S}(\mathrm{EtO}, \mathrm{PhO})]>0.101[\mathrm{~S}(\mathrm{PhO}, \mathrm{PhO})]$. In group I, however, the relative reactivities do not show consistent tendency: $k_{\mathrm{H}} \times 10^{3}\left[\mathrm{~S}\left(\mathrm{R}_{1}, \mathrm{R}_{2}\right)\right]=9.79[\mathrm{~S}(\mathrm{Me}, \mathrm{Me})]>$ $0.601[\mathrm{~S}(\mathrm{Ph}, \mathrm{Ph})]>0.330[\mathrm{~S}(\mathrm{Et}, \mathrm{Et})]>0.0491[\mathrm{~S}(i-\mathrm{Pr}, i-\mathrm{Pr})]$. The sequence of the anilinolysis rates of group III seems to be strongly dependent upon the sreric hindrance of the two ligands when excluding $\mathrm{S}(\mathrm{Ph}, \mathrm{Ph})$. However, when the anilinolysis rate is arranged with the sequence of the magnitudes of the rate constants (Table 3 ), the anilinolysis rates of $\mathrm{S}(i-\mathrm{Pr}, i$-Pr) and $\mathrm{S}(\mathrm{Et}, \mathrm{Et})$ are exceptionally slow, while that of $\mathrm{S}(\mathrm{Ph}, \mathrm{Ph})$ is exceptionally fast to be substantiated by the stereoelectronic effects. Thus, the authors conclude that the steric effects of the two ligands are major factor to determine

Table 2. Summary of Second-Order Rate Constants $\left(k_{\mathrm{H}} \times 10^{3} / \mathrm{M}^{-1} \mathrm{~s}^{-1}\right)$ with $\mathrm{C}_{6} \mathrm{H}_{5} \mathrm{NH}_{2}$ at $55.0^{\circ} \mathrm{C}$, NBO Charges at the Reaction Center $\mathrm{P}$ Atom, Brönsted Coefficients $\left(\beta_{\mathrm{X}(\mathrm{H})}\right)$, CICs $\left(\rho_{\mathrm{XY}}\right)$, DKIEs $\left(k_{\mathrm{H}} / k_{\mathrm{D}}\right)$, and Variation Trends of DKIEs with Substituent X for the Reactions of 110 with $\mathrm{XC}_{6} \mathrm{H}_{4} \mathrm{NH}_{2}\left(\mathrm{D}_{2}\right)$ in $\mathrm{MeCN}$

\begin{tabular}{|c|c|c|c|c|c|c|c|c|}
\hline Group & Substrate & $k_{\mathrm{H}} \times 10^{3 a}$ & charge at $\mathrm{P}^{c}$ & $\beta_{\mathrm{X}(\mathrm{H})}$ & $\rho_{\mathrm{XY}}$ & $k_{\mathrm{H}} / k_{\mathrm{D}}$ & Trend & Ref. \\
\hline \multirow{4}{*}{ I } & 1: S(Me,Me) & 9.79 & 1.180 & 1.28 & - & $0.74-0.95$ & $\uparrow$ & $1 \mathrm{j}$ \\
\hline & 2: S(Et,Et) & 0.330 & 1.208 & 1.12 & - & $0.90-1.37$ & $\downarrow$ & $1 p$ \\
\hline & 3: $\mathrm{S}(i-\mathrm{Pr}, i-\mathrm{Pr})$ & $0.0491^{b}$ & 1.247 & 0.97 & - & $0.80-0.96$ & $\downarrow$ & this work \\
\hline & 4: $\mathrm{S}(\mathrm{Ph}, \mathrm{Ph})$ & 0.601 & 1.236 & 1.40 & - & $1.00-1.10$ & $\uparrow$ & 1e \\
\hline \multirow{2}{*}{ II } & 5: $\mathrm{S}\left(\mathrm{Me}, \mathrm{YC}_{6} \mathrm{H}_{4} \mathrm{O}\right)$ & 7.25 & 1.432 & $0.14-0.46^{d}$ & $-0.95 /-1.11^{d}$ & $\begin{array}{l}1.03-1.30^{d} \\
037-0.57^{e}\end{array}$ & $\begin{array}{l}\uparrow \\
\uparrow\end{array}$ & $1 \mathrm{k}$ \\
\hline & 6: $\mathrm{S}\left(\mathrm{Ph}, \mathrm{YC}_{6} \mathrm{H}_{4} \mathrm{O}\right)$ & 1.50 & 1.462 & $1.22-1.33$ & $-0.38^{d}$ & $0.44-1.34$ & $\downarrow$ & $1 \mathrm{q}$ \\
\hline \multirow{4}{*}{ III } & 7: $\mathrm{S}(\mathrm{MeO}, \mathrm{MeO})$ & 1.09 & 1.687 & 0.99 & - & $0.95-1.06$ & $\uparrow$ & $1 \mathrm{~g}$ \\
\hline & 8: S(EtO,EtO) & 0.512 & 1.701 & 0.98 & - & $1.01-1.10$ & $\uparrow$ & $1 \mathrm{~g}$ \\
\hline & 9: $\mathrm{S}\left(\mathrm{EtO}, \mathrm{YC}_{6} \mathrm{H}_{4} \mathrm{O}\right)$ & 0.280 & 1.687 & $1.10-1.19$ & -0.28 & $1.06-1.27$ & $\uparrow$ & $1 \mathrm{f}$ \\
\hline & 10: $\mathrm{S}\left(\mathrm{PhO}, \mathrm{YC}_{6} \mathrm{H}_{4} \mathrm{O}\right)$ & 0.101 & 1.661 & $1.34-1.41$ & -0.22 & $1.07-1.28$ & $\uparrow$ & $1 \mathrm{c}$ \\
\hline
\end{tabular}

${ }^{a}$ The values with unsubstituted aniline $(\mathrm{X}=\mathrm{H})$, and $\mathrm{Y}=\mathrm{H}$ for $\mathbf{5}, \mathbf{6}, \mathbf{9}$, and $\mathbf{1 0}$ at $55.0^{\circ} \mathrm{C} .{ }^{b}$ Empirical value. See ref. $14 .{ }^{c} \mathrm{The}$ values with $\mathrm{Y}=\mathrm{H}$ for $\mathbf{5}, \mathbf{6}$, 9, and 10. ${ }^{d} \mathrm{X}=4-\mathrm{MeO}, 4-\mathrm{Me}$, and $\mathrm{H} .{ }^{e} \mathrm{X}=4-\mathrm{Cl}, 3-\mathrm{Cl}$, and $3-\mathrm{NO}_{2}$. 
Table 3. Sequence of the magnitudes of Second-order Rate Constants $\left(k_{2} \times 10^{3} / \mathrm{M}^{-1} \mathrm{~s}^{-1}\right)$ of the Reactions of 1-10 with $\mathrm{C}_{6} \mathrm{H}_{5} \mathrm{NH}_{2}$ in $\mathrm{MeCN}$ at $55.0^{\circ} \mathrm{C}$

\begin{tabular}{ccccccccccc}
\hline Substrate & $\mathrm{S}(\mathrm{Me}, \mathrm{Me})$ & $\mathrm{S}(\mathrm{Me}, \mathrm{PhO})$ & $\mathrm{S}(\mathrm{Ph}, \mathrm{PhO})$ & $\mathrm{S}(\mathrm{MeO}, \mathrm{MeO})$ & $\mathrm{S}(\mathrm{Ph}, \mathrm{Ph})$ & $\mathrm{S}(\mathrm{EtO}, \mathrm{EtO})$ & $\mathrm{S}(\mathrm{Et}, \mathrm{Et})$ & $\mathrm{S}(\mathrm{EtO}, \mathrm{PhO})$ & $\mathrm{S}(\mathrm{PhO}, \mathrm{PhO})$ & $\mathrm{S}(i-\mathrm{Pr}, i-\mathrm{Pr})$ \\
\hline$k_{2} \times 10^{3}$ & 9.79 & 7.25 & 1.50 & 1.09 & 0.601 & 0.512 & 0.330 & 0.280 & 0.101 & 0.0491 \\
\hline
\end{tabular}

the relative reactivities of phosphonochloridothioates and chlorothiophosphates. In group I, thiophosphinic chlorides, the steric effects of the two ligands are one of the predominant factors and the degree of the steric effects are much greater than those of groups II and III.

DKIEs on the $\mathbf{P}=\mathbf{S}$ Systems. There is no doubt that two small methyl ligands in S(Me,Me) enable backside attack of the aniline nucleophile, resulting in secondary inverse DKIEs. ${ }^{1 \mathrm{j}}$ In $\mathrm{S}(\mathrm{Et}, \mathrm{Et})^{1 \mathrm{p}}$ and $\mathrm{S}\left(\mathrm{Ph}, \mathrm{YC}_{6} \mathrm{H}_{4} \mathrm{O}\right){ }^{1 \mathrm{q}}$ the DKIEs are invariably changed from secondary inverse to primary normal as the anilines become weaker. In S(MeO,MeO), ${ }^{1 \mathrm{~g}}$ the DKIEs are invariably changed from primary normal to secondary inverse as the anilines become weaker. In $\mathrm{S}\left(\mathrm{Me}, \mathrm{YC}_{6} \mathrm{H}_{4} \mathrm{O}\right)$, the DKIEs are primary normal with the strongly basic anilines while secondary inverse with the weakly basic anilines. In $\mathrm{S}(\mathrm{Ph}, \mathrm{Ph}),{ }^{1 \mathrm{e}} \mathrm{S}(\mathrm{EtO}, \mathrm{EtO}),{ }^{1 \mathrm{~g}} \mathrm{~S}\left(\mathrm{EtO}, \mathrm{YC}_{6} \mathrm{H}_{4} \mathrm{O}\right),{ }^{1 \mathrm{f}}$ and $\mathrm{S}\left(\mathrm{PhO}, \mathrm{YC}_{6} \mathrm{H}_{4} \mathrm{O}\right){ }^{1 \mathrm{c}}$ the DKIEs are primary normal with all of the anilines. In the present work, $\mathrm{S}(i-\mathrm{Pr}, i-\mathrm{Pr})$, the DKIEs are secondary inverse and the values of $k_{\mathrm{H}} / k_{\mathrm{D}}$ invariably increase as the anilines become weaker.

In group III, the values of the DKIEs increase as the ligands $\left(\mathrm{R}_{1}\right.$ and $\left.\mathrm{R}_{2}\right)$ become larger; the greater the incidence of steric hindrance, the greater the chance of frontside attack, as a result, the greater the DKIE becomes: $k_{\mathrm{H}} / k_{\mathrm{D}}=0.95-$ $1.06[\mathrm{~S}(\mathrm{MeO}, \mathrm{MeO})]<1.01-1.10[\mathrm{~S}(\mathrm{EtO}, \mathrm{EtO})]<1.06-1.27$ $\left[\mathrm{S}\left(\mathrm{EtO}, \mathrm{YC}_{6} \mathrm{H}_{4} \mathrm{O}\right)\right]<1.07-1.28\left[\left(\mathrm{~S}\left(\mathrm{PhO}, \mathrm{YC}_{6} \mathrm{H}_{4} \mathrm{O}\right)\right]\right.$.

In group II, when one methyl or phenyl ligand is introduced into the $\mathrm{P}=\mathrm{S}$ system $\left[\mathrm{S}\left(\mathrm{Ph}, \mathrm{YC}_{6} \mathrm{H}_{4} \mathrm{O}\right)\right.$ or $\left.\mathrm{S}\left(\mathrm{Me}, \mathrm{YC}_{6} \mathrm{H}_{4} \mathrm{O}\right)\right]$, the observed DKIEs are not simple but rather unusual. The secondary inverse DKIEs could be as small as or equal to $\sim 0.4$ for both substrates: ${ }^{1 \mathrm{q}}$ (i) in $\mathrm{S}\left(\mathrm{Ph}, \mathrm{YC}_{6} \mathrm{H}_{4} \mathrm{O}\right), k_{\mathrm{H}} / k_{\mathrm{D}}=$ 0.44-1.34; (ii) in $\mathrm{S}\left(\mathrm{Me}, \mathrm{YC}_{6} \mathrm{H}_{4} \mathrm{O}\right), k_{\mathrm{H}} / k_{\mathrm{D}}=0.37$ (the unprecedented smallest value)- 0.57 for the weakly basic anilines while $k_{\mathrm{H}} / k_{\mathrm{D}}=1.03-1.30$ for the strongly basic anilines. ${ }^{1 \mathrm{k}}$ The DKIEs for $\mathrm{S}(\mathrm{YPhS}, \mathrm{Ph})$, containing one $\mathrm{Ph}$ ligand, are $k_{\mathrm{H}} / k_{\mathrm{D}}$ $=1.15-1.59$ (the largest value for $\mathrm{P}=\mathrm{S}$ systems). It is the tentative conclusion of the authors that introduction of $\mathrm{Ph}$ and/or Me ligands gives unexpected DKIEs whether the substrate is the $\mathrm{P}=\mathrm{O}$ or $\mathrm{P}=\mathrm{S}$ system.

In group I, there is no correlation between DKIEs and two ligands. The primary normal DKIEs $\left(k_{\mathrm{H}} / k_{\mathrm{D}}=1.00-1.10\right)$ of $\mathrm{S}(\mathrm{Ph}, \mathrm{Ph})$ may be acceptable since the two phenyl ligands are relatively large to prohibit backside attack. The secondary inverse DKIEs $\left(k_{\mathrm{H}} / k_{\mathrm{D}}=0.74-0.95\right)$ of $\mathrm{S}(\mathrm{Me}, \mathrm{Me})$ is reasonable since the two small methyl ligands enable backside attack. Taking into account greater size of the two $i$-Pr ligands than that of the two Et ligands, it is not easy to interpret primary normal and secondary inverse DKIEs $\left(k_{\mathrm{H}} /\right.$ $\left.k_{\mathrm{D}}=0.90-1.37\right)$ with $\mathrm{S}(\mathrm{Et}, \mathrm{Et})$ while secondary inverse DKIEs $\left(k_{\mathrm{H}} / k_{\mathrm{D}}=0.80-0.96\right)$ with $\mathrm{S}(i$-Pr, $i$-Pr $)$.

Herein, it should be noted that the real primary normal DKIE due to TSf is greater than the observed value, since the observed value is the sum of: (i) the primary normal DKIE $\left(k_{\mathrm{H}} / k_{\mathrm{D}}>1\right)$ because of the partial deprotonation of one of the two N-H(D) bonds, TS II; (ii) the secondary inverse DKIE $\left(k_{\mathrm{H}} / k_{\mathrm{D}}<1\right)$ because of the steric hindrance that increases the out-of-plane bending vibrational frequencies of the other $\mathrm{N}-\mathrm{H}(\mathrm{D})$ bond; (iii) lowering of the $k_{\mathrm{H}} / k_{\mathrm{D}}$ value because of the nonlinear and asymmetrical structure of $\mathrm{N} \cdots$ $\mathrm{H}(\mathrm{D}){ }^{\cdots} \mathrm{Cl}$; (iv) lowering of the $k_{\mathrm{H}} / k_{\mathrm{D}}$ value because of the heavy atom $(\mathrm{N}$ and $\mathrm{Cl})$ contribution of the reaction-coordinate motion. 4

Proposed Mechanism. The reaction mechanism of the anilinolyses of 1-10 in MeCN, summarized in Table 4, can be rationalized mainly through CICs and DKIEs. The negative sign of the $\rho_{\mathrm{XY}}$ value indicates that the reaction proceeds

Table 4. Summary of the Proposed Mechanism for the Reactions of 1-10 with $\mathrm{XC}_{6} \mathrm{H}_{4} \mathrm{NH}_{2}\left(\mathrm{D}_{2}\right)$ in $\mathrm{MeCN}$

\begin{tabular}{|c|c|c|c|}
\hline Substrate & $k_{\mathrm{H}} / k_{\mathrm{D}}$ & $\rho_{\mathrm{XY}}$ & Proposed mechanism \\
\hline 1: $\mathrm{S}(\mathrm{Me}, \mathrm{Me})$ & $0.74-0.95$ & - & Concerted $\mathrm{S}_{\mathrm{N}} 2 ;$ predominant backside attack $^{a}$ \\
\hline 2: $\mathrm{S}(\mathrm{Et}, \mathrm{Et})$ & $0.90-1.37$ & - & Concerted $\mathrm{S}_{\mathrm{N}} 2 ;$ backside and frontside attack $^{b}$ \\
\hline 3: $\mathrm{S}(i-\operatorname{Pr}, i-\operatorname{Pr})$ & $0.80-0.96$ & - & Concerted $\mathrm{S}_{\mathrm{N}} 2$; predominant backside attack $^{a}$ \\
\hline 4: $\mathrm{S}(\mathrm{Ph}, \mathrm{Ph})$ & $1.00-1.10$ & - & Concerted $\mathrm{S}_{\mathrm{N}} 2 ;$ backside $<$ frontside attack \\
\hline & $1.03-1.30$ & $-0.95 /-1.11$ & For strongly basic anilines: Concerted $\mathrm{S}_{\mathrm{N}} 2$; predominant frontside attack \\
\hline 5: $\mathrm{S}\left(\mathrm{Me}, \mathrm{YC}_{6} \mathrm{H}_{4} \mathrm{O}\right)$ & $0.37-0.57$ & $0.77 / 0.21$ & $\begin{array}{l}\text { For weakly basic anilines; Stepwise with rate-limiting leaving group expulsion from } \\
\text { the intermediate; predominant backside attack }\end{array}$ \\
\hline 6: $\mathrm{S}\left(\mathrm{Ph}, \mathrm{YC}_{6} \mathrm{H}_{4} \mathrm{O}\right)$ & $0.44-1.34$ & -0.38 & Concerted $\mathrm{S}_{\mathrm{N}} 2$; backside and frontside attack \\
\hline 7: $\mathrm{S}(\mathrm{MeO}, \mathrm{MeO})$ & $0.95-1.06$ & - & Concerted $\mathrm{S}_{\mathrm{N}} 2$; backside and frontside attack \\
\hline 8: S(EtO,EtO) & $1.01-1.10$ & - & Concerted $\mathrm{S}_{\mathrm{N}} 2 ;$ backside $<$ frontside attack \\
\hline 9: $\mathrm{S}\left(\mathrm{EtO}, \mathrm{YC}_{6} \mathrm{H}_{4} \mathrm{O}\right)$ & $1.06-1.27$ & -0.28 & Concerted $\mathrm{S}_{\mathrm{N}} 2 ;$ predominant frontside attack \\
\hline 10: $\mathrm{S}\left(\mathrm{PhO}, \mathrm{YC}_{6} \mathrm{H}_{4} \mathrm{O}\right)$ & $1.07-1.28$ & -0.22 & Concerted $\mathrm{S}_{\mathrm{N}} 2$; predominant frontside attack $^{b}$ \\
\hline
\end{tabular}

${ }^{a}$ Backside attack indicates that the reaction proceeds involving an in-line-type TSb. ${ }^{b}$ Frontside attack indicates that the reaction proceeds involving a hydrogen-bonded, four-center-type TSf. 
through a concerted $\mathrm{S}_{\mathrm{N}} 2$ mechanism, while the positive sign of the $\rho_{\mathrm{XY}}$ value indicates that the reaction proceeds through a stepwise mechanism with a rate-limiting leaving group departure from the intermediate. ${ }^{7}$

For the anilinolysis of $\mathrm{S}\left(\mathrm{Ph}_{,} \mathrm{YC}_{6} \mathrm{H}_{4} \mathrm{O}\right), \mathrm{S}\left(\mathrm{EtO}, \mathrm{YC}_{6} \mathrm{H}_{4} \mathrm{O}\right)$, and $\mathrm{S}\left(\mathrm{PhO}, \mathrm{YC}_{6} \mathrm{H}_{4} \mathrm{O}\right)$, a concerted $\mathrm{S}_{\mathrm{N}} 2$ mechanism is proposed on the basis of a negative $\rho_{\mathrm{XY}}$ value. For the anilinolysis of $\mathrm{S}(\mathrm{YPhO}, \mathrm{Me})$, a concerted $\mathrm{S}_{\mathrm{N}} 2$ mechanism is proposed on the basis of the negative $\rho_{\mathrm{XY}}$ value for the strongly basic anilines, while a stepwise mechanism with a ratelimiting leaving group departure from the intermediate is proposed on the basis of a positive $\rho_{\mathrm{XY}}$ value for the weakly basic anilines. For the anilinolysis of $\mathrm{S}(\mathrm{EtO}, \mathrm{EtO}), \mathrm{S}(\mathrm{MeO}, \mathrm{MeO})$, $\mathrm{S}(\mathrm{Ph}, \mathrm{Ph})$, and $\mathrm{S}(\mathrm{Me}, \mathrm{Me})$, a concerted $\mathrm{S}_{\mathrm{N}} 2$ mechanism was proposed on the basis of selectivity parameters ( $\rho_{\mathrm{X}}$ and $\beta_{\mathrm{X}}$ ) and DKIEs.

The attacking direction of the aniline nucleophile is manifested by the magnitude of the DKIE, since backside attack involving the in-line-type TSb results in the secondary inverse DKIE, $k_{\mathrm{H}} / k_{\mathrm{D}}<1$, while frontside attack involving a hydrogen bonded, four-center-type TS II results in the primary normal DKIE, $k_{\mathrm{H}} / k_{\mathrm{D}}>1$. The attacking direction of aniline nucleophile can be semi-quantitatively divided into four groups on the basis of the magnitudes of the $k_{\mathrm{H}} / k_{\mathrm{D}}$ values: (i) predominant backside attack when $k_{\mathrm{H}} / k_{\mathrm{D}}<1 ; k_{\mathrm{H}} /$ $k_{\mathrm{D}}=0.74-0.95[\mathrm{~S}(\mathrm{Me}, \mathrm{Me})],{ }^{1 \mathrm{j}}$ and $0.80-0.96[\mathrm{~S}(i-\mathrm{Pr}, i-\mathrm{Pr})]$; (ii) backside and frontside attacks when the $k_{\mathrm{H}} / k_{\mathrm{D}}$ values change from less than unity to greater than unity; 0.90$1.37[\mathrm{~S}(\mathrm{Et}, \mathrm{Et})]^{1 \mathrm{p}} \quad 0.95-1.06[\mathrm{~S}(\mathrm{MeO}, \mathrm{MeO})]^{1 \mathrm{~g}}$ and $0.44-1.34$ $\left[\mathrm{S}\left(\mathrm{Ph}, \mathrm{YC}_{6} \mathrm{H}_{4} \mathrm{O}\right)\right]{ }^{1 / \mathrm{q}}$ (iii) the fraction of the frontside attack is greater than that of backside attack when $1.0<k_{\mathrm{H}} / k_{\mathrm{D}}<1.1$ : $1.01-1.10[\mathrm{~S}(\mathrm{EtO}, \mathrm{EtO})]^{1 \mathrm{~g}}$ and $1.00-1.10[\mathrm{~S}(\mathrm{Ph}, \mathrm{Ph})] ;^{1 \mathrm{e}}$ (iv) predominant frontside attack when $k_{\mathrm{H}} / k_{\mathrm{D}}>1.1 ; 1.11-1.33$ $\left[\mathrm{S}\left(\mathrm{PhO}, \mathrm{YC}_{6} \mathrm{H}_{4} \mathrm{O},\right)\right],{ }^{1 \mathrm{c}}$ and $1.06-1.27\left[\mathrm{~S}\left(\mathrm{EtO}, \mathrm{YC}_{6} \mathrm{H}_{4} \mathrm{O}\right)\right],{ }^{1 \mathrm{f}} \mathrm{In}$ $\mathrm{S}\left(\mathrm{Me}, \mathrm{YC}_{6} \mathrm{H}_{4} \mathrm{O}\right)$, predominant frontside attack for the strongly basic anilines and predominant backside attack for the weakly basic anilines are proposed based on the $k_{\mathrm{H}} / k_{\mathrm{D}}$ values, $1.03-1.30$ and $0.37-0.57$, respectively. ${ }^{1 \mathrm{k}}$

In general, the fraction of the frontside nucleophilic attack of the $\mathrm{P}=\mathrm{S}$ system is greater than that of the $\mathrm{P}=\mathrm{O}$ system because of the greater electrophilicity of reaction center $\mathrm{P}$ in $\mathrm{P}=\mathrm{O}$ compared to $\mathrm{P}=\mathrm{S}$. In other words, when the degree of steric hindrance is more or less significant, the lesser electrophilicity of $\mathrm{P}$ in $\mathrm{P}=\mathrm{S}$ leads to a frontside attack with a hydrogen bonded four-center-type TSf rather than a backside attack. Meanwhile, the greater electrophilicity of $\mathrm{P}$ in $\mathrm{P}=\mathrm{O}$ overcomes the steric hindrance and enables a backside attack until the severe steric hindrance prohibits backside attack and consequently frontside attack becomes predominant.

Substituent Effects on DKIEs. In the in-line-type TSb, the greater the degree of bond formation, the greater the secondary inverse DKIE, and the smaller the magnitude of DKIE becomes. On the contrary, in the hydrogen bonded, four-center-type TSf, the greater the extent of hydrogen bond formation, the greater the primary normal DKIE, and the greater the magnitude of DKIE becomes. Thus, when the anilinolysis proceeds predominantly through backside nucleophilic attack involving TSb, the obtained values of secondary inverse DKIEs are inversely proportional to the degree of bond formation. When the anilinolysis proceeds predominantly through frontside attack involving TSf, the observed values of primary normal DKIEs may be proportional to the extent of hydrogen bond formation. When both backside and frontside attack occur simultaneously, the obtained values of DKIEs are the sum of both the secondary inverse and primary normal. The substituent $\mathrm{X}$ effects on DKIEs for the reactions of 1-10 with anilines in $\mathrm{MeCN}$ are discussed by grouping into three parts, a-c, as follows.

a: The substituent $X$ effects on secondary inverse DKIEs $\left(k_{\mathrm{H}} / k_{\mathrm{D}}<1\right)$ depend on the mechanism: (i) In the case of predominant backside nucleophilic attack involving an $\mathrm{S}_{\mathrm{N}} 2$ mechanism, the $k_{\mathrm{H}} / k_{\mathrm{D}}$ value becomes systematically greater with a stronger nucleophile, denoted as $\uparrow$ in $[\mathrm{S}(\mathrm{Me}, \mathrm{Me})]$ (Table 2). ${ }^{1 \mathrm{j}}$ A weaker nucleophile approaches a closer proximity to the reaction center P. Thus, the extent of bond formation increases as the nucleophile becomes weaker, consistent with that expected from the More O'FerrallJencks diagram. ${ }^{15}$ (ii) In $[\mathrm{S}(i-\mathrm{Pr}, i-\mathrm{Pr})]$, a stronger nucleophile approaches a closer proximity to the reaction center $\mathrm{P}$. Thus, the extent of bond formation increases as the nucleophile becomes stronger, inconsistent with that expected from the More O'Ferrall-Jencks diagram. (iii) In $\mathrm{S}\left(\mathrm{Me}, \mathrm{YC}_{6} \mathrm{H}_{4} \mathrm{O}\right.$, when $\mathrm{X}=\left(4-\mathrm{Cl}, 3-\mathrm{Cl}, 3-\mathrm{NO}_{2}\right)$ involving a stepwise mechanism with a rate-limiting leaving group expulsion, the variation of the $k_{\mathrm{H}} / k_{\mathrm{D}}$ value depends on $\mathrm{Y}: \uparrow$ for $\mathrm{Y}=(4-$ $\mathrm{MeO}, 4-\mathrm{Me}, \mathrm{H})$, while $\downarrow$ for $\mathrm{Y}=(3-\mathrm{Cl}, 4-\mathrm{CN})$, i.e., the break region between $\mathrm{Y}=\mathrm{H}$ and 3-Cl. This implies that a weaker nucleophile approaches a closer proximity to the reaction center for an electron-donating $\mathrm{Y}\left(\min . k_{\mathrm{H}} / k_{\mathrm{D}}=0.40\right.$ when $\mathrm{X}$ $=3-\mathrm{NO}_{2}$ and $\mathrm{Y}=4-\mathrm{MeO}$ ), while a stronger nucleophile approaches a closer proximity to the reaction center for an electron-withdrawing $\mathrm{Y}\left(\mathrm{min} . k_{\mathrm{H}} / k_{\mathrm{D}}=0.37\right.$ when $\mathrm{X}=4-\mathrm{Cl}$ and $\mathrm{Y}=4-\mathrm{CN}){ }^{1 \mathrm{k}}$

b: The substituent $X$ effects on the primary normal DKIEs $\left(k_{\mathrm{H}} / k_{\mathrm{D}}>1\right)$ are roughly divided into two groups: (i) The $k_{\mathrm{H}} /$ $k_{\text {D }}$ value becomes systematically greater with a stronger nucleophile, denoted as $\uparrow$, implying that a more basic aniline leads to greater hydrogen bond formation, $\mathrm{S}(\mathrm{EtO}, \mathrm{EtO})$, $\mathrm{S}\left(\mathrm{Me}, \mathrm{YC}_{6} \mathrm{H}_{4} \mathrm{O}\right.$,) when $\mathrm{X}=(4-\mathrm{MeO}, 4-\mathrm{Me}, \mathrm{H})$, and $\mathrm{S}(\mathrm{Ph}, \mathrm{Ph})$; (ii) The $k_{\mathrm{H}} / k_{\mathrm{D}}$ value becomes systematically greater with a weaker nucleophile, denoted as $\downarrow$, implying that a less basic aniline leads to a greater extent of hydrogen bond formation, e.g., S(Et,Et). The $k_{\mathrm{H}} / k_{\mathrm{D}}$ value does not change systematically, denoted as $\uparrow$, but rather closer to the trends of $\downarrow$, $\mathrm{S}\left(\mathrm{PhO}, \mathrm{YC}_{6} \mathrm{H}_{4} \mathrm{O}\right)$ and $\mathrm{S}\left(\mathrm{EtO}, \mathrm{YC}_{6} \mathrm{H}_{4} \mathrm{O}\right)$.

c: The substituent $\mathrm{X}$ effects on DKIEs with both primary normal and secondary inverse are exemplified in two cases: (i) In $\mathrm{S}(\mathrm{MeO}, \mathrm{MeO})$, the $k_{\mathrm{H}} / k_{\mathrm{D}}$ value becomes systematically greater with a stronger nucleophile, denoted as $\uparrow$; (ii) In $\mathrm{S}\left(\mathrm{Ph}, \mathrm{YC}_{6} \mathrm{H}_{4} \mathrm{O}\right)$, the $k_{\mathrm{H}} / k_{\mathrm{D}}$ value becomes systematically greater with a weaker nucleophile, denoted as $\downarrow$. As can be seen in a-c, the substituent effects of nucleophile (X) on DKIEs are not simple but complicate, and depend on sub- 
strates, reaction mechanism, and the type of DKIEs (primary normal and/or secondary inverse). The trends of the substituent effects on DKIEs sometimes show consistencies such as the substituent $\mathrm{X}$ effects on secondary inverse or primary normal DKIEs.

\section{Experimental Section}

Materials. The starting materials, chlorodiisopropylphosphine $(96 \%)$ and THF (more than 99.9\%) were used for the synthesis of diisopropyl thiophosphinic chloride. HPLC grade acetonitrile (water content is less than $0.005 \%$ ) was used for kinetic studies without further purification. Anilines were redistilled or recrystallized before use as previously described. ${ }^{1}$ Deuterated anilines were synthesized by heating anilines and deuterium oxide ( 99.9 atom \% D) and one drop of $\mathrm{HCl}$ as catalyst at $85^{\circ} \mathrm{C}$ for 72 hours, and after numerous attempts, anilines were deuterated more than $98 \%$, as confirmed by ${ }^{1} \mathrm{H}$ NMR. Diisopropyl thiophosphinic chloride was prepared by the following one step synthetic route. ${ }^{1 \mathrm{p}, 16}$ Chlorodiisopropylphosphine was stirred overnight with sulfur in THF. The solvent was removed under reduced pressure and a colorless liquid product was isolated through column chromatography ( $10 \%$ ethyl acetate $+n$-hexane). Analytical and spectroscopic data of the product gave the following results:

$(\boldsymbol{i}-\mathbf{P r})_{2} \mathbf{P}(=\mathbf{S}) \mathbf{C l}$. Colorless liquid; ${ }^{1} \mathrm{H}$ NMR $(400 \mathrm{MHz}$, $\left.\mathrm{CDCl}_{3}\right) \delta 1.28-1.36\left(\mathrm{~m}, 12 \mathrm{H}, 4 \mathrm{CH}_{3}\right), 2.45-2.47(\mathrm{~m}, 2 \mathrm{H}, 2$ $\mathrm{CH}) ;{ }^{13} \mathrm{C}$ NMR $\left(100 \mathrm{MHz}, \mathrm{CDCl}_{3}\right) \delta 16.02-16.33\left(\mathrm{CH}_{3}, i-\right.$ $\mathrm{Pr}), 34.79,35.30(\mathrm{CH}, i-\mathrm{Pr}) ;{ }^{31} \mathrm{P}$ NMR $\left(162 \mathrm{MHz}, \mathrm{CDCl}_{3}\right) \delta$ $-112.92(\mathrm{~s}, 1 \mathrm{P}, \mathrm{P}=\mathrm{S}) ; \mathrm{m} / z, 184\left(\mathrm{M}^{+}\right)$.

Kinetic Procedure. Rates were measured conductometrically at $65.0{ }^{\circ} \mathrm{C}$. The conductivity bridge used in this work was a self-made computer automated $\mathrm{A} / \mathrm{D}$ converter conductivity bridge. Pseudo-first-order rate constants, $k_{\text {obsd }}$ were measured by curve fitting analysis in origin program with a large excess of anilines, [Substrate] $=5 \times 10^{-3} \mathrm{M}$ and [XAniline $]=(0.5-0.9) \mathrm{M}$. Second-order rate constants, $k_{2}$, were obtained from the slope of a plot of $k_{\mathrm{obsd}} v s$. [X-Aniline] with five concentrations of anilines. The $k_{\text {obsd }}$ values were the average of three runs, which were reproducible within $\pm 3 \%$.

Product Analysis. Diisopropyl thiophosphinic chloride was reacted with excess 4-methoxyaniline, for more than 15 half-lives at $65.0^{\circ} \mathrm{C}$ in $\mathrm{MeCN}$. The 4-methoxy aniline hydrochloride salt was separated by filtration. Acetonitrile was evaporated under reduced pressure. The product was isolated with ether by a work-up process and dried over anhydrous $\mathrm{MgSO}_{4}$. After filtration the product was isolated by evaporating the solvent under reduced pressure. The Analytical and spectroscopic data of the product after column chromatography (silica gel $/ 35 \%$ ethyl acetate $+n$ hexane) were:

$(i-\mathbf{P r})_{2} \mathbf{P}(=\mathbf{S}) \mathbf{N H C}_{6} \mathbf{H}_{\mathbf{4}}-\mathbf{4}-\mathbf{C H}_{3} \mathbf{O}$. Dark-brown solid; mp $(102-103){ }^{\circ} \mathrm{C} ;{ }^{1} \mathrm{H}$ NMR $\left(400 \mathrm{MHz}, \mathrm{CDCl}_{3}\right) \delta 1.15-1.36(\mathrm{~m}$, $\left.12 \mathrm{H}, 4 \mathrm{CH}_{3}, i-\mathrm{Pr}\right), 2.30-2.39$ (m, $\left.2 \mathrm{H}, 2 \mathrm{CH}, i-\mathrm{Pr}\right), 3.76$ (s, $\left.3 \mathrm{H}, \mathrm{CH}_{3} \mathrm{O}\right), 4.05$ (s, $\left.1 \mathrm{H}, \mathrm{NH}\right), 6.76-6.79(\mathrm{~d}, J=7.6 \mathrm{~Hz}, 2 \mathrm{H}$, phenyl), 7.01-7.03 (d, $J=8.8 \mathrm{~Hz}, 2 \mathrm{H}$, phenyl); ${ }^{13} \mathrm{C}$ NMR $\left(100 \mathrm{MHz}, \mathrm{CDCl}_{3}\right) \delta 16.39-16.74\left(\mathrm{CH}_{3}, i\right.$ - $\left.\mathrm{Pr}\right), 29.68,30.28$ $(\mathrm{CH}, i-\mathrm{Pr}), 55.49\left(\mathrm{CH}_{3} \mathrm{O}\right), 114.45,122.71,122.75(\mathrm{C}=\mathrm{C}$, aromatic); ${ }^{31} \mathrm{P} \mathrm{NMR}\left(162 \mathrm{MHz}, \mathrm{CDCl}_{3}\right) \delta 92.11$ (s, $\left.1 \mathrm{P}, \mathrm{P}=\mathrm{S}\right)$; $m / z, 271\left(\mathrm{M}^{+}\right)$.

Acknowledgments. This work was supported by the Brain Korea 21 Program from National Research Foundation of Korea and Inha University Research Grant.

\section{References and Notes}

1. (a) Guha, A. K.; Lee, H. W.; Lee, I. J. Chem. Soc., Perkin Trans. 2 1999, 765. (b) Lee, H. W.; Guha, A. K.; Lee, I. Int. J. Chem. Kinet. 2002, 34, 632. (c) Hoque, M. E. U.; Dey, S.; Guha, A. K.; Kim, C. K.; Lee, B. S.; Lee, H. W. J. Org. Chem. 2007, 72, 5493. (d) Hoque, M. E. U.; Lee, H. W. Bull. Korean Chem. Soc. 2007, 28, 936. (e) Dey, N. K.; Han, I. S.; Lee, H. W. Bull. Korean Chem. Soc. 2007, 28, 2003. (f) Hoque, M. E. U.; Dey, N. K.; Kim, C. K.; Lee, B. S.; Lee, H. W. Org. Biomol. Chem. 2007, 5, 3944. (g) Dey, N. K.; Hoque, M. E. U.; Kim, C. K.; Lee, B. S.; Lee, H. W. J. Phys. Org. Chem. 2008, 21, 544. (h) Lumbiny, B. J.; Lee, H. W. Bull. Korean Chem. Soc. 2008, 29, 2065. (i) Dey, N. K.; Hoque, M. E. U.; Kim, C. K.; Lee, B. S.; Lee, H. W. J. Phys. Org. Chem. 2009, 22, 425. (j) Dey, N. K.; Kim, C. K.; Lee, H. W. Bull. Korean Chem. Soc. 2009, 30, 975. (k) Hoque, M. E. U.; Guha, A. K.; Kim, C. K.; Lee, B. S.; Lee, H. W. Org. Biomol. Chem. 2009, 7 , 2919. (1) Dey, N. K.; Lee, H. W. Bull. Korean Chem. Soc. 2010, 31, 1403. (m) Dey, N. K.; Kim, C. K.; Lee, H. W. Org. Biomol. Chem. 2011, 9, 717. (n) Barai, H. R.; Lee, H. W. Bull. Korean Chem. Soc. 2011, 32, 1939. (o) Hoque, M. E. U.; Lee, H. W. Bull. Korean Chem. Soc. 2011, 32, 1997. (p) Hoque, M. E. U.; Lee, H. W. Bull. Korean Chem. Soc. 2011, 32, 2306. (q) Adhikary, K. K.; Lumbiny, B. J.; Dey, S.; Lee, H. W. Bull. Korean Chem. Soc. 2011, 32, 2628.

2. (a) Guha, A. K.; Lee, H. W.; Lee, I. J. Org. Chem. 2000, 65, 12. (b) Lee, H. W.; Guha, A. K.; Kim, C. K.; Lee, I. J. Org. Chem. 2002, 67, 2215. (c) Adhikary, K. K.; Lee, H. W.; Lee, I. Bull. Korean Chem. Soc. 2003, 24, 1135. (d) Hoque, M. E. U.; Dey, N. K.; Guha, A. K.; Kim, C. K.; Lee, B. S.; Lee, H. W. Bull. Korean Chem. Soc. 2007, 28, 1797. (e) Adhikary, K. K.; Lumbiny, B. J.; Kim, C. K.; Lee, H. W. Bull. Korean Chem. Soc. 2008, 29, 851. (f) Lumbiny, B. J.; Adhikary, K. K.; Lee, B. S.; Lee, H. W. Bull. Korean Chem. Soc. 2008, 29, 1769. (g) Dey, N. K.; Hoque, M. E. U.; Kim, C. K.; Lee, H. W. J. Phys. Org. Chem. 2010, 23, 1022. (h) Dey, N. K.; Adhikary, K. K.; Kim, C. K.; Lee, H. W. Bull. Korean Chem. Soc. 2010, 31, 3856. (i) Dey, N. K.; Kim, C. K.; Lee, H. W. Bull. Korean Chem. Soc. 2011, 32, 709. (j) Hoque, M. E. U.; Dey, S.; Kim, C. K.; Lee, H. W. Bull. Korean Chem. Soc. 2011, 32, 1138. (k) Guha, A. K.; Hoque, M. E. U.; Lee, H. W. Bull. Korean Chem. Soc. 2011, 32, 1375. (1) Guha, A. K.; Kim, C. K.; Lee, H. W. J. Phys. Org. Chem. 2011, 24, 474. (m) Adhikary, K. K.; Lee, H. W. Bull. Korean Chem. Soc. 2011, 32, 1945. (n) Hoque, M. E. U.; Lee, H. W. Bull. Korean Chem. Soc. 2011, 32, 2109. (o) Barai, H. R.; Lee, H. W. Bull. Korean Chem. Soc. 2011, 32, 2339. (p) Hoque, M. E. U.; Lee, H. W. Bull. Korean Chem. Soc. 2011, 32, 2805.

3. Adhikary, K. K.; Lee, H. W. Bull. Korean Chem. Soc. 2011, 32, 1625.

4. (a) Lee, I.; Kim, C. K.; Li, H. G.; Sohn, C. K.; Kim, C. K.; Lee, H. W.; Lee, B. S. J. Am. Chem. Soc. 2000, 122, 11162. (b) Han, I. S.; Kim, C. K.; Lee, H. W. Bull. Korean Chem. Soc. 2011, 32, 889.

5. (a) Poirier, R. A.; Youliang, W.; Westaway, K. C. J. Am. Chem. Soc. 1994, 116, 2526. (b) Yamata, H.; Ando, T.; Nagase, S.; Hanamusa, M.; Morokuma, K. J. Org. Chem. 1984, 49, 631. (c) Xhao, X. G.; Tucker, S. C.; Truhlar, D. G. J. Am. Chem. Soc. 1991, 113,826 . 
6. (a) Melander, L., Jr.; Saunders, W. H. Reaction Rates of Isotopic Molecules; Wiley-Interscience: New York, 1980. (b) Lee, I.; Koh, H. J.; Lee, B. S.; Lee, H. W. J. Chem. Soc., Chem. Commun. 1990, 335.

7. (a) Lee, I. Chem. Soc. Rev. 1990, 19, 317. (b) Lee, I. Adv. Phys. Org. Chem. 1992, 27, 57. (c) Lee, I.; Lee, H. W. Collect. Czech. Chem. Commun. 1999, 64, 1529.

8. Hehre, W. J.; Random, L.; Schleyer, P. V. R.; Pople, J. A. Ab Initio Molecular Orbital Theory; Wiley: New York, 1986; Chapter 4.

9. (a) Ritchie, C. D. In Solute-Solvent Interactions; Coetzee, J. F., Ritchie, C. D., Eds.; Marcel Dekker: New York, 1969; Chapter 4. (b) Coetzee, J. F. Prog. Phys. Org. Chem. 1967, 4, 54. (c) Spillane, W. J.; Hogan, G.; McGrath, P.; King, J.; Brack, C. J. Chem. Soc., Perkin Trans. 2 1996, 2099. (d) Oh, H. K.; Woo, S. Y.; Shin, C. H.; Park, Y. S.; Lee, I. J. Org. Chem. 1997, 62, 5780.

10. Perrin and coworkers reported that the basicities of $\beta$-deuterated analogs of benzylamine, $\mathrm{N}, \mathrm{N}$-dimethylaniline and methylamine increase roughly by $0.02 \mathrm{p} K_{\mathrm{a}}$ units per deuterium, and that these effects are additive; (a) Perrin, C. I.; Engler, R. E. J. Phys. Chem. 1991, 95, 8431. (b) Perrin, C. I.; Ohta, B. K.; Kuperman, J. J. Am.
Chem. Soc. 2003, 125, 15008. (c) Perrin, C. I.; Ohta, B. K.; Kuperman, J.; Liberman, J.; Erdelyi, M. J. Am. Chem. Soc. 2005, $127,9641$.

11. Hansch, C.; Leo, A.; Taft, R. W. Chem. Rev. 1991, 91, 165.

12. Streitwieser, A., Jr.; Heathcock, C. H.; Kosower, E. M. Introduction to Organic Chemistry, 4th ed.; Macmillan: New York, 1992; p 735.

13. Crumpler, T. B.; Yoh, J. H. Chemical Computations and Errors; John Wiley: New York, 1940; p 178.

14. The second-order rate constants of the anilinolysis of $\mathbf{3}$ with unsubstituted anline $\left(\mathrm{C}_{6} \mathrm{H}_{5} \mathrm{NH}_{2}\right)$ in $\mathrm{MeCN}$ are measured as follows: $k_{\mathrm{H}}=0.0491 \pm 0.0004\left(45.0{ }^{\circ} \mathrm{C}\right), 0.0681 \pm 0.0004(55.0$ ${ }^{\circ} \mathrm{C}$ ), and $0.0910 \pm 0.0006 \times 10^{-3} \mathrm{M}^{-1} \mathrm{~s}^{-1}\left(65.0^{\circ} \mathrm{C}\right)$. Enthalpy of activation of $\Delta H^{ \pm}=13.0 \pm 0.2 \mathrm{kcal} \mathrm{mol}^{-1}$ and entropy of activation of $\Delta S^{ \pm}=-39 \pm 1 \mathrm{cal} \mathrm{mol}^{-1} \mathrm{~K}^{-1}$ are obtained for the reaction of 3 with aniline $\left(\mathrm{C}_{6} \mathrm{H}_{5} \mathrm{NH}_{2}\right)$ in $\mathrm{MeCN}$ at $65.0^{\circ} \mathrm{C}$.

15. (a) More O'Ferrall, R. A. J. Chem. Soc. B 1970, 274. (b) Jencks, W. P. Chem. Rev. 1972, 72, 705.

16. Birdsall, D. J.; Slawin, A. M. Z.; Woollins, J. D. Polyhedron 2001, 20,125 . 